\title{
Trichoderma pseudokoningii Showed Compatibility with Certain Commonly used Inorganic Pesticides, Fertilizers and Sticker Cum Spreaders
}

\author{
Pranab Dutta*, N. Kakati, A. Das, H. Kaushik, S. Boruah, P. Bhowmick, P. Kaman, \\ K.C. Puzari, R.P. Bhuyan and G.N. Hazarika \\ Department of Plant Pathology, Faculty of Agriculture, Assam Agricultural University, \\ Jorhat-785013, Assam, India \\ *Corresponding author
}

\section{A B S T R A C T}

\begin{tabular}{l} 
Ke y w o r d s \\
Inorganic fertilizers, \\
Pesticides, \\
$\begin{array}{l}\text { Sticker, } \\
\text { Trichoderma } \\
\text { pseudokoningii }\end{array}$ \\
\hline Article Info \\
$\begin{array}{l}\text { Accepted: } \\
\text { 05 January } 2017 \\
\text { Available Online: } \\
\text { 10 February } 2017\end{array}$ \\
\hline
\end{tabular}

\section{Keyw ords}

Inorganic fertilizers, Pesticides,

Sticker,

Trichoderma

Article Info

Accepted:

Available Online

10 February 2017
Trichoderma pseudokoningii was tested for its compatibility with 11 insecticides, 7 fungicides, 2 herbicides, 1 sticker cum spreader, 4 different inorganic fertilizers in in vitro by poinson food technique. All the pesticides were tested for their compatibility with $T$. pseudokoningii at two different concentrations i.e., recommended dose (RD) and half of the RD and four different were tested for inorganic fertilizer and organic sticker cum spreader. All the pesticides significantly inhibited the mycelial growth of the fungus $T$. pseudokoningii except Thiamethonaus $25 \% \mathrm{WG}$ at $0.125 \%$. Ritha at all the tested doses was found compatible with the biocontrol gaent. Urea and muriate of potash were found compatible with $T$. pseudokoningii while single super phosphate and calcium ammonium nitrate inhibited its growth. The observed variations in the inhibitory potential could be due to inherent variability of chemical insecticide to biocontrol agents, $T$. pseudokoningii . CAN inhibited the colony growth of $T$. pseudokoningii at all the tested concentrations. Present investigations showed varying effects of pesticides, sticker, inorganic fertilizers on the fungi, their actual effects at cellular and field level need to be investigated to understand if the effects are permanent or temporary.

\section{Introduction}

Biological management refers the exploitation of beneficial fungal and bacterial microorganisms to attack and the disease caused by different pathogens. Biological management is gaining importance because of the deleterious effect of agrochemicals. It is an environmentally safe approach to curb plant diseases and pests. Fungal biocontrol agents like Trichoderma spp. has been identified as a potential agents for the management of the wide pathogenic range like Fusarium spp., Rhizoctonia solani, Sclerotium rolfsii, Sclerotinia sclerotiorum,
Macrophomina phaseolina and root knot nematode, Meloidogyne incognita (Shylaja and Rao, 2012). It is known that biotic and abiotic factors influence the biocontrol efficacy of Trichoderma (Kredics et al., 2003).

Inorganic pesticides (Insecticides, fungicides, herbicides) and fertilizers (Urea, SSP, MOP and CAN) have played a vital role in supplementing the plant nutrients that get depleted during long term mono-cropping and land cultivation and to curb the biotic stresses. 
Further for better efficacy in rainy days sticker and spreader are also used by the farmers.

The most promising possibility for the application of Trichoderma strains is within the framework of integrated plant protection management, based on the combined application of all the possible management tactics like physical, chemical and biological means.

The fungal biocontrol agents and selective fertilizer, pesticides may act synergistically increasing the efficiency of the control, allowing lower doses of pesticides, preserving natural enemies, minimizing environmental pollution and decreasing the likelihood of development of resistance to either agent (Moino and Alves, 1998; Ambettiger, 2009). Further, compatible combination can reduce the cost of cultivation by reducing the time of application of different component singly.

\section{Materials and Methods}

A starin of $T$. psedokoningii maintained at Indian Type Culture Collection (ITCC), Indian sgricultural Research Institute (IARI) New Delhi, India with accession number ITCC no. 8885.12 which was found to be effective against Colletotrichum capsici, Fusarium solani, Rhizoctonia solani, Sclerotinia sclerotiorum and Sclerotium rolfsii was used for the experiment. In all, 11 insecticides, 7 fungicides, 2 herbicides, 1 sticker cum spreader, 4 different inorganic fertilizers were used in the study. The In vitro bio efficacy of the inorganic pesticides, fertilizers and organic sticker were determined using poisoned food technique (Nene and Thapliyal, 1997). All the pesticides were tested for their compatibility with $T$. pseudokoningii at two different concentrations ie., recommended dose (RD) and half of the RD. Sticker cum spreader was tested for their compatibility at three different does. On the basis of the contents of different elements different concentrations viz. $0.1 \%$, $0.2 \%, 0.5 \%, 1 \%, 2 \%$ of the inorganic fertilizers were tested for their compatibility with the $T$. pseudokoningii. Each of the pesticides, sticker and inorganic fertilizers was added along with streptomycin sulphate at $0.3 \mathrm{~g} / 1$ to autoclaved but unset potato dextrose agar (PDA) separately in conical flasks and stirred until dissolved completely.

For control appropriate amount of streptomycin sulphate alone was added in the PDA media. About $15 \mathrm{ml}$ of PDA with dissolved pesticides or stickers or inorganic fertilizers was poured into hot air oven sterilized petriplate $(90 \mathrm{~mm}$ diameter) under sterile conditions and left to solidify. A $7 \mathrm{~mm}$ mycelia disc from 4 days old fresh culture of T. pseudokoningii was inoculated at the centre of each petriplate and incubated at $25-28^{\circ} \mathrm{C}$ for 5-7 days. One set of petridish of PDA without the addition of any pesticides or stickers or inorganic fertilizer was maintained as a control. Each treatment was replicated for five times. The diameter of the fungal colony in each petriplate was recorded by taking the average of 10 measurements at different direction per petriplate.

The percent growth inhibition in the colony diameter was calculated by using the formula

Percent inhibition $=\frac{\mathrm{C}-\mathrm{T}}{\mathrm{C}} \times 100$

Where, $\mathrm{C}=$ colony diameter in control $\mathrm{T}=$ Colony diameter in treatments

The percent increase in the colony diameter was calculated using the following formula

Percent inhibition $=\frac{\mathrm{C}-\mathrm{T}}{\mathrm{C}} \times 100$ 
Where, $\mathrm{T}=$ Colony diameter in treatments $\mathrm{C}=$ Colony diameter in control

The data were statistically analysed and critical difference $(C D)$ calculated at $\mathrm{P}=0.05$

\section{Results and Discussion}

Among the chemicals tested for compatibility all the pesticides significantly inhibited the mycelial growth of the fungus $T$. pseudokoningii at recommended and half of the recommended doses except Thiamethonaus $25 \% \mathrm{WG}$ at $0.125 \%$ and Imidacloprid $17.8 \% \mathrm{SL}$ at $0.2 \%$ and $0.1 \%$ (Table 1). Captan 50\% WP at $0.25 \%$, Carbendazim $12 \%$ + Mancozeb $63 \%$ at $0.25 \%$ and $0.125 \%$, Carbendazim 50\% WP at $0.05 \%$ and $0.025 \%$ and Difenoconazole $25 \% \mathrm{EC}$ at $0.125 \%$ and $0.25 \%$ were found highly detrimental to the fungus by retarding the growth totally to $100 \%$. This was followed by Lambdacyhalothrin 5\% EC at $0.25 \%$ and $0.50 \%$ and Paraquat dichloride $24 \%$ SL at $0.30 \%$ which inhibited the growth to an extent of $94.66 \%$ and $93.92 \%$ respectively.

There was no significant difference between Captan 50\% WP at $0.25 \%$, Carbendazim 12\% + Mancozeb $63 \%$ at $0.25 \%$ and $0.125 \%$, Carbendazim 50\% WP at $0.05 \%$ and $0.025 \%$, Difenoconazole $25 \%$ EC at $0.25 \%$ and $0.125 \%$, Lambdacyhalothrin $5 \%$ EC at $0.25 \%$ and Paraquat dichloride $24 \%$ SL at $0.30 \%$ in inhibition of the radial growth of $T$. pseudokoningii. Bhatt and Srivastava (2003) found that Mancozeb exhibited fungistatic action against $T$. viride while copper oxychloride inhibited the growth of Trichoderma spp to a maximum extent. Maximum growth of the fungus was recorded in Thiamethoxam $25 \% \mathrm{WG}$ at $0.125 \%$, and Imidacloprid $17.8 \% \mathrm{SL}$ at $0.2 \%$ and $0.1 \%$ with no inhibition on growth of the fungus. Methomyl $40 \% \mathrm{~W} / \mathrm{W}$ at $0.02 \%$ and Mancozeb $75 \% \mathrm{WP}$ at $0.125 \%$ was found compatible with the fungus with $7.29 \mathrm{~cm}$ and $7.24 \mathrm{~cm}$ radial growth of the fungus. As such the chemicals were found to be compatible compared to rest of the chemicals tested thiamethonaus $25 \% \mathrm{WG}$ at $0.125 \%$ and imidacloprid $17.8 \% \mathrm{SL}$ at $0.2 \%$ and $0.1 \%$ were found safe to the fungus, as there was no inhibition of growth. Methomyl $40 \% \mathrm{~W} / \mathrm{W}$ at $0.02 \%$ and mancozeb $75 \% \mathrm{WP}$ at $0.125 \%$ was found compatible with less detrimental effects (18.96\% and $19.58 \%$ respectively) on the inhibition of growth of the fungus. The safety of imidachloprid to Trichoderma was also observed by Bhat and Sabalpara (2001), Vijayaraghavan and Abraham (2004). It was also found that the growth of $T$. pseudokoningii was more in recommended dose of Lambdacyhalothrin 5\% EC and Metalaxyl-M 4\% + Mancozeb 64\% $1.42 \mathrm{~cm}$ and $4.02 \mathrm{~cm}$ respectively than half of the recommended dose $0.48 \mathrm{~cm}$ and $3.84 \mathrm{~cm}$ respectively.

The observed variations in the inhibitory potential could be due to inherent variability of chemical insecticide to biocontrol agents, T. pseudokoningii. Their inhibitory potential varies both between and within chemical classes (Inglis et al., 2001). A given insecticides may have different fungitoxic effects on various developmental stages of the fungus ( $\mathrm{Li}$ and Holdom, 1994). The potential inhibitory effects of pesticides on germination and mycelia growth of biocontrol fungi vary from taxa and strains (Anderson et al., 1989). However results may differ in field because fungi are exposed maximum to pesticides In vitro which doesn't occur under field conditions. Additionally, fungi may recover after some chemical pesticides are decomposed on plant leaves. Therefore, once a chemical insecticide is proved to be compatible in the laboratory, it must be selective in field conditions. On the other hand, high In vitro toxicity of the product will not always be same in the field (Butt and Brownbridge, 1997) but is likely to be occur (Alves et al., 1998). 
Table.1 In vitro compatibility of Trichoderma pseudokoningii with chemicals

\begin{tabular}{|c|c|c|c|c|}
\hline Pesticides & Treatment & Dose (\%) & $\begin{array}{ll}\text { Colony } & \text { diameter } \\
(\mathrm{mm}) & *\end{array}$ & $\begin{array}{l}\text { \% Mycelial growth } \\
\text { inhibition }\end{array}$ \\
\hline & Control & - & $0.90^{\mathrm{q}}$ & 100 \\
\hline \multirow[t]{22}{*}{ Insecticides: } & \multirow[t]{2}{*}{ Deltamethrin $2.8 \%$ EC } & 0.014 & $16.30^{\mathrm{cd}}$ & 81.85 \\
\hline & & 0.028 & $12.70^{\mathrm{cd}}$ & 85.92 \\
\hline & \multirow[t]{2}{*}{ Quinalphos 25\% EC } & 0.0125 & $34.30^{\mathrm{hij}}$ & 61.81 \\
\hline & & 0.025 & $23.80^{\mathrm{ef}}$ & 73.55 \\
\hline & \multirow[t]{2}{*}{ Dimethoate $30 \%$ EC } & 0.030 & $25.80^{\mathrm{fg}}$ & 71.25 \\
\hline & & 0.060 & $11.30^{\mathrm{bc}}$ & 87.40 \\
\hline & \multirow[t]{2}{*}{ Chlorpyriphos 20\% EC } & 0.010 & $18.90^{\mathrm{de}}$ & 78.96 \\
\hline & & 0.020 & $15.40^{\mathrm{cd}}$ & 82.88 \\
\hline & \multirow[t]{2}{*}{ Propargite 57\%EC } & 0.100 & $31.30^{\text {gh }}$ & 65.81 \\
\hline & & 0.200 & $18.80^{\mathrm{de}}$ & 79.03 \\
\hline & \multirow[t]{2}{*}{ Malathion 50 \% EC } & 0.075 & $49.20^{\operatorname{lm}}$ & 45.33 \\
\hline & & 0.150 & $22.90^{\mathrm{eff}}$ & 74.51 \\
\hline & \multirow[t]{2}{*}{ Methomyl $40 \%$ W/W } & 0.020 & $72.90^{\mathrm{p}}$ & 18.96 \\
\hline & & 0.040 & $57.50^{\mathrm{no}}$ & 36.07 \\
\hline & \multirow[t]{2}{*}{ Thiamethonaus 25\% WG } & 0.125 & $0.90^{\mathrm{q}}$ & 0.00 \\
\hline & & 0.050 & $51.80^{\mathrm{mn}}$ & 42.44 \\
\hline & \multirow[t]{2}{*}{ Diafenthiuron 50\% WP } & 0.040 & $41.80^{\mathrm{K}}$ & 53.48 \\
\hline & & 0.080 & $37.50^{\mathrm{ijk}}$ & 58.29 \\
\hline & \multirow[t]{2}{*}{ Imidacloprid $17.8 \%$ SL } & 0.200 & $0.09^{\mathrm{q}}$ & 0.00 \\
\hline & & 0.100 & $0.09^{\mathrm{q}}$ & 0.00 \\
\hline & \multirow{2}{*}{ Lambdacyhalodrin5\% EC } & 0.250 & $0.05^{\mathrm{a}}$ & 94.66 \\
\hline & & 0.500 & $14.20^{\mathrm{cd}}$ & 84.22 \\
\hline \multirow[t]{12}{*}{ Fungicides: } & \multirow[t]{2}{*}{ Captan 50\% WP } & 0.125 & $0.00^{\mathrm{a}}$ & 100.00 \\
\hline & & 0.250 & $0.00^{\mathrm{a}}$ & 100.00 \\
\hline & \multirow{2}{*}{$\begin{array}{l}\text { Carbendazim 12\% + Mancozeb } \\
63 \%\end{array}$} & 0.125 & $0.00^{\mathrm{a}}$ & 100.00 \\
\hline & & 0.250 & $0.00^{\mathrm{a}}$ & 100.00 \\
\hline & \multirow[t]{2}{*}{ Carbendazim 50\% WP } & 0.025 & $0.00^{\mathrm{a}}$ & 100.00 \\
\hline & & 0.050 & $0.00^{\mathrm{a}}$ & 100.00 \\
\hline & \multirow{2}{*}{$\begin{array}{l}\text { Metalaxyl-M 4\% + Mancozeb } \\
64 \%\end{array}$} & 0.125 & $38.40^{\mathrm{ijk}}$ & 57.33 \\
\hline & & 0.250 & $40.20^{\mathrm{jk}}$ & 55.33 \\
\hline & \multirow[t]{2}{*}{ Mancozeb 75\% WP } & 0.125 & $72.40^{\mathrm{P}}$ & 19.58 \\
\hline & & 0.250 & $43.10^{\mathrm{k}}$ & 52.07 \\
\hline & \multirow{2}{*}{ Difenoconazole 25\% EC } & 0.125 & $0.00^{\mathrm{a}}$ & 100.00 \\
\hline & & 0.250 & $0.00^{\mathrm{a}}$ & 100.00 \\
\hline \multirow[t]{4}{*}{ Herbicides: } & \multirow[t]{2}{*}{ Glyphosate $41 \%$ SL } & 0.150 & $61.70^{\circ}$ & 31.40 \\
\hline & & 0.300 & $32.50^{\text {hi }}$ & 63.81 \\
\hline & \multirow[t]{2}{*}{ Paraquate Dichloride 24\% SL) } & 0.150 & $15.70^{\mathrm{cd}}$ & 82.51 \\
\hline & & 0.300 & $0.054^{\mathrm{ab}}$ & 93.92 \\
\hline $\mathrm{CD}(\mathrm{P}=0.05)$ & & & 0.60 & \\
\hline
\end{tabular}

*Data are mean of four replications,

Mean followed same letter are at par with each other. 
Table. 2 Compatibility of Trichoderma pseudokoningii with different concentration of commonly used inorganic fertilizers

\begin{tabular}{|c|c|c|c|c|c|c|c|c|}
\hline \multirow{2}{*}{$\begin{array}{c}\text { Concentration } \\
\text { of inorganic } \\
\text { fertilizer }(\%)\end{array}$} & \multicolumn{2}{|c|}{ Urea } & \multicolumn{2}{|c|}{$\begin{array}{c}\text { Single super } \\
\text { phosphate (SSP) }\end{array}$} & \multicolumn{2}{|c|}{$\begin{array}{c}\text { Muriate of potash } \\
\text { (MOP) }\end{array}$} & \multicolumn{2}{|c|}{$\begin{array}{l}\text { Calcium ammonium } \\
\text { nitrate (CAN) }\end{array}$} \\
\hline & $\begin{array}{c}\text { Colony } \\
\text { diameter } \\
(\mathbf{m m})\end{array}$ & $\begin{array}{c}\% \\
\text { increase } \\
\text { over } \\
\text { control }\end{array}$ & $\begin{array}{c}\text { Colony } \\
\text { diameter } \\
(\mathrm{mm})\end{array}$ & $\begin{array}{c}\% \\
\text { increase } \\
\text { over } \\
\text { control }\end{array}$ & $\begin{array}{c}\text { Colony } \\
\text { diameter } \\
(\mathrm{mm})\end{array}$ & $\begin{array}{c}\% \\
\text { increase } \\
\text { over } \\
\text { control }\end{array}$ & $\begin{array}{c}\text { Colony } \\
\text { diameter } \\
(\mathbf{m m})\end{array}$ & $\begin{array}{c}\% \\
\text { increase } \\
\text { over } \\
\text { control }\end{array}$ \\
\hline Control & 70.00 & - & 70.00 & - & 70.00 & - & 70.00 & - \\
\hline 0.1 & 72.00 & +2.86 & 64.00 & -8.57 & 73.20 & +4.57 & 67.00 & -4.29 \\
\hline 0.2 & 74.00 & +5.41 & 60.00 & -14.29 & 76.40 & +8.38 & 64.00 & -7.14 \\
\hline 0.5 & 79.00 & +12.86 & 58.00 & -27.71 & 80.30 & +12.83 & 61.66 & -11.91 \\
\hline 1.0 & 84.00 & +20.00 & 50.00 & -28.57 & 90.00 & +28.57 & 59.40 & -15.14 \\
\hline 2.0 & 90.00 & +28.57 & 47.40 & -32.29 & 90.00 & +28.57 & 33.00 & -52.86 \\
\hline $\begin{array}{c}\text { CD } \\
(P=0.05)\end{array}$ & 3.26 & - & 3.47 & - & 3.33 & - & 2.48 & - \\
\hline
\end{tabular}

*Data are mean of five replications

Table.3 Compatibility of Trichoderma pseudokoningii with organic sticker

\begin{tabular}{|l|c|c|c|}
\hline \multicolumn{1}{|c|}{ Treatment } & Dose (\%) & Colony diameter (mm)* & $\begin{array}{l}\text { \%ycelial } \\
\text { inhibition }\end{array}$ \\
\hline \multirow{3}{*}{ Ritha } & 0.0025 & 90.00 & 0.00 \\
\cline { 2 - 4 } & 0.005 & 90.00 & 0.00 \\
\cline { 2 - 4 } & 0.010 & 88.00 & 2.23 \\
\cline { 2 - 4 } & 0.020 & 85.00 & 5.56 \\
\hline $\begin{array}{l}\text { Control } \\
\text { (T. pseudokoningii) }\end{array}$ & - & 90.00 & - \\
\hline CD (P=0.05) & & & \\
\hline
\end{tabular}

*Data are mean of five replications

When data presented in table 2 showed urea and muriate of potash were compatible with T. pseudokoningii while single super phosphate and calcium ammonium nitrate inhibited its growth. At $0.1 \%$ and $0.2 \%$ urea did not affect the growth of $T$. pseudokoningii.

The colony diameter of $T$. pseudokoningii increases slowly with the increase in concentration of urea from $0.1 \%, 0.2 \%, 0.5 \%$ and $1 \%$. At $2 \%$ concentration of urea significantly highest colony diameter of 90 $\mathrm{mm}$ diameter was observed with $28.57 \%$ increase of growth over control. In this study none of the concentrations of urea tested inhibited fungal growth (Table 2).
With SSP, the fungal growth was inhibited at all the tested concentrations. At $0.1 \%$ the colony was restricted to $64.00 \mathrm{~mm}$ as against the $70 \mathrm{~mm}$ in the control with a significant inhibition of $8.57 \%$. At $0.2 \%, 0.5 \%, 1 \%$ and $2 \%$ the colony diameters were $60 \mathrm{~mm}$, $50.6 \mathrm{~mm}, 50 \mathrm{~mm}$ and $47.4 \mathrm{~mm}$ respectively. The values were at par with each other, but the inhibition was significantly greater than at $0.1 \%$. the corresponding percent inhibition were $14.29 \%, 27.71 \%, 28.57 \%$ and $32.29 \%$ respectively for $0.2 \%, 0.5 \%, 1 \%$ and $2 \%$ concentration.

CAN inhibited the colony growth of $T$. pseudokoningii at all the tested 
concentrations. The largest inhibition was recorded at $0.1 \%$ with a colony diameter of 67 $\mathrm{mm}$ and significantly smaller than the control (70 mm). At $0.2 \%$ the colony diameter was 64 $\mathrm{mm}$ and significantly different from $0.1 \%$ concentration. The colony diameter of the fungus was $61.66 \mathrm{~mm}$ and $59.4 \mathrm{~mm}$ at $0.5 \%$ and $1 \%$ respectively, where were statistically at par with each other but significantly less than those in control and $0.2 \%$ concentration.

Earlier worker Sharma et al., (1999) reported the incompatibility of $T$. harzianum with calcium nitrate at higher concentration. Similarly they also reported the compatibility of T. harzianum and Pochonia chlamydosporia with urea, superphosphate and muriate of potash (Table 3 ).

Present investigations showed varying effects of pesticides, sticker, inorganic fertilizers on the fungi, their actual effects at cellular and field level need to be investigated to understand if the effects are permanent or temporary. In case of temporary arrest of fungus activity, it may recover after degradation of toxicant and such chemicals can be employed in combination with the fungus under field conditions. The results are of permanent importance for both the development of protocols for fermentation technology and field applications of the application and efficacy of biocontrol agents.

\section{References}

Alves, S.B., Moino, Jr. A. and Almeida, J.E.M. 1998. Produtos fitossanitarios e entomopathogenos. In: Controle microbiano de insectos. Piracicaba. (Ed): S.B. Alves. FEALQ, pp. 217-238.

Anderson, T.E., Hajek, A., Roberts, D.W., Preisler, K. and Robertyson, J.L. 1989. Colorado potato beetyle (Coleoptera: Chrysomelidae): Effects of combinations of Beauveria bassiana with insecticides. J. Econ. Entomol., 82(1): 83-89.
Anonymous. 1994. Pests of Tea in north east India and their conrol; Memo no. 27 (Jorhat: Tocklai Experimental Station.

Bhat and Sabalpara, A.N. 2001. Sensitivity of some bio-inoculants to pesticides. J. Mycol. Plant Pathol., 31: 267.

Bhat, N.M. and Srivastava, L.S. 2003. Evaluation of some fungicides and neem formulations against six soil borne pathogens and three Trichodema spp. In vitro. Plant Dis. Res., Ludhiana, 18: 56-59.

Butt, T.M. and Brownbridge, M. 1997. Fungal pathogens of thrips. In: Thrips as crop pests. (Ed.): T. Lewis. CAB international, Wallingford, UK. Pp. 399- 433.

Chandler, D., Davidson, G., Grant, W.P., Greaves, J., Tatchell, G.M. 2008. Microbial biopesticides for integrated crop management: an assessment of environmental and regulatory sustainability, Trends Food Sci. Technol., 19: 275-283.

Chen, Z. and Chen, X. 1989. An analysis of the world tea pests fauna. J. Tea Sci., 9: 1322.

Dayakar, S.K., Kanaujia, R. and Rathore, R.R.S. 2000. Compatibility of entomopathogenous fungi with commonly used insecticides for management of Spodoptera litura (Fab.). In: Microbials in Insect Pest Management. (Eds.): S. Ignacimuthu and A. Sen. Oxford and IBH Publishing Co. Pvt. Ltd, M. Delhi Kolkata, pp. 47-52.

Desai, S.A. and Srikant, K. 2004. Effect of fungicides, insecticies and weedicides on the growth and sporulation of native Trichoderma harzianum Rifai. Karnataka J. Agri. Sci., 17: 57-62.

Duarte, A., Menendez, J.M. and Trigueiro, N. 1992. Estudio preliminary sobre la compatibilidad de Metarhizium anisopliae com algunos plaguicidas quimicos. Revista Baracoa, 22: 31-39.

Gupta, P., Paul, M.S. and Sharma, S.N. 1999. Studies on compatibility of white muscardine fungus Beauveria bassiana with neem products. Indian Phytopathol., 52(3): 278- 280. 
Hazarika, L.K. and Puzari, K.C. 2001. Microbials in Tea pests management. In: Microbial in insect pests Management (Eds. S. Ignacimuthu ND A. Sen) Oxford and IBH Publishing Co. Pvy. Ltd., New Delhi, pp. 99-104.

Inglis, G.D., Goettel, M.S. and Strasser, H. 2001. Use of hyphomycetous fungi for managing insect pests. In: Fungi as Biocontrol agents progress, problems and potentials.(Eds): T.M. Butt, C. Jackson and N. Nagan. Wallingford, UK: CABI publishing. pp. 23-70.

Li, D.P. and Holdom, D.G. 1994. Effects of pesticides on growth and sporulation of Metarhizium anisopliae(Deutromycotina: Hypomycets). J. Invertebr. Pathol., 63: 209-211.

Malo, A.R. 1993. Estudio sobre la compatibilidad del hongo Beauveria bassiana (Bals.) Vuill. Con formulaciones comerciales de fungicidas e insecticidas. Revista Colombiana de Entomologia, 19: 151-158.

Moino, Jr. A.R. and Alves, S.B. 1998. Efeito de Imidachloprid e Fipronil sobre Beauveria bassiana (Bals.) Vuill. E Metarhirzium anesopliae (Metsch.) Sorok. E no comportamento de limpeza de Heterotermies tenuis (Hagem). Anais da Sociedade Entomologica do Brasil, 27: 611-619.

Muraleedharan, N. 1992. Pest control in Asia. In: Tea cultivation to consumption K.C.
Wilson and M.N. Clifford (eds.) London, Chapman and Hall, pp. 375 - 411.

Nene, Y.L. and Thaplial, P.N. 1997. Fungicides in Plant Disease Control. Oxford and IBH Publishing Co. Pvt. Ltd., New Delhi, p. 531.

Oliveria, G.N., Neves, P.M.O.J. and Kawazoe, L.S. 2003. Compatibility between the entomopathogenic fungus Beauveria bassiana and insecticides used in coffee plantations. Scientia Agricola, 60 (4): 663667.

Serebrov, V.V., Khodyrev, V.P., Gerber, O.N. and Tsvetkova, V.P. 2005. Per spectives of combined use of entomopathogenic fungi and chemical insecticides against Colorado Beetle (Leptinotarsa decemlineata). Mikologiya I Fitopatologiya, 39(3): 89-98

Tiwari, R.K.S., Rajput, M.L., Singh, A. and Thakur, B.S. 2004. Nontarget effect of insecticides on the mycelial growth of Trichoderma harzianum (Rifai). Indian J. Plant Protection Sci., 32: 140-141.

Vanninen, I. and Hokkanen, H. 1988. Effects of pesticides on four species of entomopathogenic fungi. Ann. Agri. Fenn., 27: 345-353.

Vijayaraghavan, R. and Abraham, K. 2004. Compatibility of biocontrol agents with pesticides and fertilizers used in black pepper gardens. J. Mycol. Plant Pathol., 34: 506-510.

\section{How to cite this article:}

Pranab Dutta, N. Kakati, A. Das, H. Kaushik, S. Boruah, P. Bhowmick, P. Kaman, K.C. Puzari, R.P. Bhuyan and Hazarika, G.N. 2017. Trichoderma pseudokoningii Showed Compatibility with Certain Commonly used Inorganic Pesticides, Fertilizers and Sticker Cum Spreaders. Int.J.Curr.Microbiol.App.Sci. 6(2): 140-146. doi: http://dx.doi.org/10.20546/ijcmas.2017.602.020 